value was realised in Great Britain. The potato survived a great volume of scom, and was finally introduced to cultivation through sheer necessityit mitigated the hardships of several famines. $\mathrm{Mr}$. Bunyard suggests, somewhat whimsically, that lilies and tulips are edible, and appeals for an extension of "the Elizabethan spirit of adventure in the vegetable garden".

\section{Sir Henry Wellcome, F.R.S.}

THE President of the French Republic has paid a notable tribute to English medical and chemical research by conferring the honour of La Croix de Chevalier de la Légion d'Honneur upon Sir Henry Wellcome, who has also just been awarded the Remington medal of the American Pharmaceutical Association for distinguished service to pharmacy. Sir Henry is founder of the Wellcome Research Institution and head of Burroughs Wellcome and Co., London, manufacturers of fine chemicals and galenicals, with establishments in the United States, Italy, Canada, Australia, India, China, South Africa, the Argentine and other countries. Apart from the research and experimental laboratories of the establishments of Burroughs Wellcome and Co. which have carried out many original researches in pharmacy, Sir Henry Wellcome has established a number of scientific research laboratories and research museums which are co-ordinated under separate and distinct direction, such as the Wellcome Research Institution with its magnificent new building in Euston Road, London. In these associated chemical and medical research laboratories and museums, much original work has been done to throw light on abstruse problems in medicine and pharmacy and to settle hitherto uncertain points in the history of pharmacy.

\section{Royal Irish Academy}

AT the stated meeting on March 16 of the Royal Irish Academy, the following members were elected : Prof. K. G. Emeléus, professor of physics, Queen's University of Belfast; Prof. T. T. Flynn, professor of zoology, Queen's University of Belfast; Dr. R. H. Hunter, senior lecturer in anatomy, Queen's University of Belfast; Rev. J. Hynes, professor of archæology, University College, Galway; Rev. G. V. Jourdan, professor of ecclesiastical history, University of Dublin ; Prof. M. F. Liddell, professor of German, University of Dublin ; Mr. C. Blake Whelan, archæologist. The Abbé Victor Grégoire has been elected. an honorary member in the Department of Science and Prof. Ellis H. Minns, Prof. Michael Rostovtzeff and Prof. Jean B. Vendryes honorary members in the Department of Polite Literature and Antiquities.

\section{Announcements}

THE first Royal Society soirée this year will be held in the Society's rooms at Burlingtion House on May 9 and the second on June 20.

Prof. A. M. Carr-Saunders, Charles Booth professor of social science, University of Liverpool, has been elected a member of the Athenæum under the provisions of Rule II of the club, which empowers the annual election by the committee of a certain number of persons of distinguished eminence in science, literature, the arts or for public service.

Prof. H. LEvy, professor of mathematics at the Imperial College of Science, will deliver the twentyfifth Conway Memorial Lecture on Wednesday, April 25, at 7 p.m. at Conway Hall, Red Lion Square, W.C.1, his subject being "Science in an Irrational Society". Admission will be free.

THE Academy of Sciences of the U.S.S.R. has elected the following to honorary membership of the Society: Sir Frederick Gowland Hopkins, Cambridge; Prof. G. H. Hardy, Cambridge; Dr. E. Schrödinger, Berlin (now Oxford); Prof. David Hilbert, Göttingen; Prof. Max Born, Göttingen (now Cambridge) ; Prof. T. Levi-Civita, Rome; and Prof. Carl Starmer, Oslo. Prof. Vainio Tanner, Helsingfors, has been elected a corresponding member.

The Hillebrand Prize of the Chemical Society of Washington for the year 1933 has been awarded to the late Dr. Edward Wight Washburn for the discovery of the first practical method of separating the isotopes of hydrogen. He discovered the electrolytic method of separation, which has made possible the subsequent research into the properties of the isotopes of hydrogen, and has thus initiated almost a new era in chemistry, consequent upon the differences in the chemical and physical properties of these isotopes and their compounds.

ThE Council of the Iron and Steel Institute announces that His Majesty the King has been graciously pleased to accept the Bessemer Gold Medal of the Institute for 1934. His Majesty has been the patron of the Iron and Steel Institute since his accession. The Bessemer Gold Medal was founded in 1873 by the late Sir (then Mr.) Henry Bessemer, the discoverer of the Bessemer process of steelmaking and the second president of the Iron and Steel Institute. It has been awarded annually since that date to distinguished benefactors of the industry and particularly for pre-eminent contributions towards the scientific and technical knowledge of iron and steel. In 1899 Queen Victoria, and in 1906 King Edward VII, agreed to be recipients of this Medal.

Applications are invited for the following appoint. ments, on or before the dates mentioned :-A general manager for the Pigs Marketing Board-The Secretary, Pigs Marketing Board, Thames House, Millbank, London, S.W.1 (April 9). A public analyst for the Dorset County Council-The Clerk of the County Council, County Offices, Dorchester (April 18). A teacher of mathematics, and a teacher of applied mechanics and machine drawing, at the Junior Technical School, Sheffield-The Chief Education Officer, Leopold Street, Sheffield (April 19). A senior assistant librarian at University College, Hull-The Registrar (April 20). A temporary resident lecturer (woman) in history and geography at the Hereford Training College-The Principal. 